\title{
Współpraca naukowa PRL $z$ drugą Jugosławią
}

AвSTRACt: Małczak Leszek, Wspólpraca naukowa PRL z druga Jugosławia (Scientific Cooperation Between Polish People's Republic and the Second Yugoslavia). "Poznańskie Studia Slawistyczne" 19. Poznań 2020. Publishing House of the Poznań Society for the Advancement of the Arts and Sciences, Adam Mickiewicz University, pp. 117-133. ISSN 2084-3011.

Scientific connections between Polish People's Republic and The Second Yugoslavia were a very important element of the bilateral relations between both countries. The mechanisms and rules of the scientific cooperation were similar to the rules and mechanisms of the cultural cooperation and faced the same constraints and possibilities. Types of institutions existing in the field of culture had their correspondences in the field of science and education. Developing of the scientific cooperation was not a strategic aim for both countries in the interwar period as well as during the Communism due to the situation on the international political scene. In the era of globalization, in the context of international scientific cooperation, interslavic relations has become the weakest in the last two centuries. Nowadays, even more than before, the scientific cooperation between all Slavic countries depends on individuals and their involvement.

KeYwords: scientific cooperation; institutions; Polish People's Republic; The Second Yugoslavia

W niniejszym artykule będzie mowa o mechanizmach i zasadach współpracy naukowej PRL z drugą Jugosławią. Opis modelu kooperacji oparty jest na analizach i kwerendach dokumentów przeprowadzonych w archiwach Ministerstwa Spraw Zagranicznych, Ministerstwa Kultury i Dziedzictwa Narodowego, w Archiwum Akt Nowych, Archiwum Jugosławii oraz Chorwackim Archiwum Państwowym. Moje dotychczasowe badania i publikacje dotyczyły relacji kulturalnych, przede wszystkim w zakresie literatury, oraz instytucji, które się nimi zajmowały. W zebranych materiałach znajdują się również informacje na temat kontaktów naukowych i instytucji za nie odpowiedzialnych (na potrzeby tego artykułu przeanalizowałem kilka tysięcy kopii dokumentów pochodzących z wcześniej wymienionych źródeł). 
Badań i publikacji na temat współpracy naukowej Polski z Jugosławią jest bardzo niewiele. Kilka artykułów dotyczących tej problematyki ukazało w serii wieloautorskich monografii będących owocem współdziałania polskich i serbskich historyków z uniwersytetów w Bydgoszczy oraz w Belgradzie (z udziałem przedstawicieli innych dyscyplin i ośrodków), a poświęconych szeroko rozumianym polsko-jugosłowiańskim kontaktom. W 2014 roku we wspomnianej serii ukazał sią artykuł Dragomira Bondžicia pt. Wspótpraca jugosłowiańskich i polskich uniwersytetów w latach 1945-1960. Serbski historyk podzielił w nim omawiany okres na 3 fazy, wyróżniając dwa kluczowe momenty: Rezolucję Kominformu (1948 rok) oraz połowę lat 50., czyli normalizację stosunków. Ostatnia data, rok 1960, nie stanowi żadnej cezury. Swą analizę Bondžić podsumowuje tezą mówiącą o tym, że współpraca naukowa, uniwersytecka i kulturalna po wznowieniu stosunków, zerwanych w 1948 roku, znalazła się pod znacznie mniejszą presją czynników ideologiczno-politycznych. Idzie nawet dalej, gdyż stwierdza, że z czasem o jej kształcie zaczęły decydować względy naukowe i profesjonalne oraz potrzeby naukowych instytucji, badaczy i studentów (Bondžić, 2014, 321). Przyglądając się kolejnym dekadom opisywanego w niniejszym artykule okresu, przełomowe okazują się: połowa lat 60 . wraz z zachodzącą w Jugosławii decentralizacją dziedziny współpracy kulturalnej i naukowej z zagranicą oraz lata 70 . wraz z procesem odprężenia w stosunkach międzynarodowych. Ocena całego okresu jest trudna i niejednoznaczna. Czasy komunizmu, w zależności od indywidulanych doświadczeń i poglądów, spotykają się ze skrajnymi osądami. Z jednej strony w ówczesnych realiach społecznych, politycznych i ekonomicznych dyktat państwa i ideologii pozostawał czynnikiem decydującym, z drugiej strony ,wolności" w sferze wymiany kulturalnej i naukowej jako kształtującej wizerunek Polski i analogicznie Jugosławii w świecie były w porównaniu do innych dziedzin życia społecznego większe.

Cały okres PRL, choć złożony i niejednolity, w dziedzinie współpracy naukowej z zagranicą charakteryzuje jedna podstawowa cecha - jej kształt, rozwój i dynamika były ściśle uzależnione od sytuacji politycznej na arenie międzynarodowej. Z jednej strony zagraniczna polityka naukowa poszczególnych państw, podobnie jak zagraniczna polityka kulturalna, wiązała się z wewnętrzną, krajową polityką naukową, z drugiej strony stanowiła część zagranicznej polityki państwa. W tym kontekście znamienny okazuje się 
już sam tytuł rozprawy autorstwa Edwarda Haliżaka Wspótpraca naukowo-techniczna Wschód-Zachód, ponieważ właśnie ówczesny bipolarny podział polityczny świata determinował międzynarodowe stosunki naukowe. Haliżak na początku swojej pracy stwierdza, że jej przedmiotem jest ,analiza właściwości współpracy naukowo-technicznej w powiązaniu z prawidłowościami stosunków między krajami o odmiennych ustrojach społeczno-politycznych" (Haliżak, 1988, 6). Powiązania świata nauki i kultury ze sferą polityki nie są czymś wyjątkowym. Nie są zjawiskiem ograniczonym do jakiegoś okresu, typowym dla określonego systemu politycznego czy ustroju. Byłoby naiwnością myślenie o nauce i uniwersytecie, w jakimkolwiek czasie i miejscu, jako instytucjach zupełnie autonomicznych i politycznie niezależnych. Mówimy tu o naturalnych i oczywistych związkach, jakie między tymi dziedzinami występują. Tezę stawianą przez Magdalenę Najbar-Agičić w odniesieniu do periodyzacji historii historiografii w dobie komunizmu w krajach Europy Środkowej, która według badaczki pokrywa się z rozwojem sytuacji politycznej w tych krajach i w której powiązania pomiędzy obydwiema sferami są znacznie silniejsze niż w krajach o demokratycznych ustrojach, możemy przenieść na całą sferę kontaktów kulturalnych i naukowych (Najbar-Agičić, 2013b, 2). Specyfika opisywanego okresu polega na tym, że mówimy o niedemokratycznych państwach, których ustrój cechował brak rywalizacji politycznej oraz niewystępowanie różnych czynników i ośrodków wpływu czy pluralizmu politycznego. Presja ideologiczna była wówczas tak silna, że wszystko wydawało się polityczne i upolitycznione. Ponadto w (neo)marksizmie sferę nauki i kultury zalicza się do nadbudowy ideologicznej, czyli tych instytucji i idei, które umacniają istniejące ,stosunki produkcji” i służą ich rozwojowi (służą reprodukcji stosunków społecznych). Dlatego przywiązywano do nich bardzo dużą wagę i partia te sfery starała się kontrolować, nie dopuszczając do głosu treści niezgodnych z panującą ideologią. Ze względu na bezpośredni wpływ na wyobrażenia społeczne większą uwagę poświęcano nadzorowaniu sfery kultury niż nauki. W nauce zaś ważniejsze były uniwersytety jako instytucje edukacyjne i kształcące niż akademie, o czym pisze amerykański historyk John Connelly: 
także elity, albo, by użyć określenia Kurta Hagera, wschodnioniemieckiego szefa do spraw ideologii - dowódców (Connelly, 2014, 11).

Tytuł monografii profesora historii Europy Środkowo-Wschodniej na Uniwersytecie Kalifornijskim w Berkley, której przekład ukazał się w serii wydawniczej PAN Monografie z Dziejów Oświaty, mógłby sugerować, że dokonał się w PRL proces zniewalania polskich uniwersytetów, akademii i nauki. Tymczasem w książce jej autor udowadnia i pokazuje, że polskiej inteligencji, poprzez ciągłą grę z komunistycznym systemem, partią i ideologią, udało się obronić tę instytucję przed tytułowym procesem sowietyzacji, choć ocena tego okresu wciąż jest daleka od jednomyślności ${ }^{1}$ Warto podkreślić, że większe politycznie znaczenie miały nauki społeczne i humanistyczne aniżeli nauki przyrodnicze, o czym na podstawie analiz zapisów stenograficznych z posiedzeń Komisji Ideologicznej Komitetu Centralnego Komunistycznej Partii Chorwacji pisze w swojej książce Magdalena Najbar-Agičić (2013a, 92). Niemniej, nauka, a zwłaszcza szczególnie narażona na naciski ideologiczne humanistyka, wykształciła różne mechanizmy obronne neutralizujące presję czynnika politycznego. Dlatego sprowadzanie nauki i uniwersytetów do podmiotów będących na usługach państwa, jakiejś konkretnej ideologii, byłoby przejawem niezrozumienia natury tych instytucji oraz ich instrumentalizacją.

Współpraca naukowa w omawianym okresie wyraźnie dzieli się na naukowo-techniczną (obejmowała nauki przyrodnicze i techniczne) oraz w innych dziedzinach. Jako przedstawiciel nauk humanistycznych skupię się w tym tekście na nich właśnie, zwłaszcza przez wzgląd na ich ścisłe powiązanie ze sferą kulturalną. Należy jednak zauważyć, że opracowania, które powstawały na ten temat, dotyczyły na ogół tych pierwszych. W jednej z monografii poświęconych zagranicznej polityce naukowo-technicznej PRL, pisanej u schyłku tegoż państwa (wydana w 1989), na samym początku Przedmowy czytamy:

${ }^{1} \mathrm{Na}$ uniwersytetach wg sowieckiego modelu ograniczano badania naukowe, przekształcano je w instytucje o funkcjach dydaktycznych, a działalność naukową koncentrowano w instytutach akademii nauk. Proces sowietyzacji polskich uniwersytetów i nauki ostatecznie się nie powiódł, a akademia nauk, w niektórych sferach, stała się, wg określenia Janusza Sławińskiego, rezerwatem, swoistą oazą większych swobód. O rezerwatach Sławiński mówił w rozmowie, jaka została przeprowadzona z „Kulturą Niezależną” 25 maja 1988 roku (Sławiński, 1990, 233). 
Zagraniczna polityka naukowo-techniczna stanowi przedłużenie polityki naukowo-technicznej państwa na obszar jego stosunków z otoczeniem zagranicznym. Obejmuje ona więc zespół celów, środków i instrumentów organizujących działania państwa na rzecz maksymalizacji korzyści narodowych z tytułu międzynarodowego podziału pracy w sferze nauki i techniki. W związku z powyższym pozostaje ona w silnym związku z zagraniczną polityką ekonomiczną oraz polityką zagraniczną państwa (Monkiewicz, Monkiewicz, Ruszkiewicz, 1989, 5).

O tym, że nauki przyrodnicze i techniczne miały pierwszeństwo, świadczy harmonogram podpisywanych umów międzyrządowych w połowie lat 50. XX wieku, w okresie normalizacji stosunków z Jugosławią. W lutym 1955 roku została podpisana umowa handlowa, następnie w listopadzie umowa o współpracy naukowo-technicznej, a w lutym 1956 roku umowa o współpracy kulturalnej. Szybki kryzys do jakiego doszło wskutek uchwalenia nowego programu Związku Komunistów Jugosławii w 1958 roku, wpłynął na kontakty kulturalne, ale nie zaburzył, przykładowo, kontaktów w zakresie energii nuklearnej (Bondžić, 2015, 295).

Historia międzynarodowej wymiany naukowej ma wiele wspólnego z historią wymiany kulturalnej. Spośród wszystkich narodów i kultur byłej Jugosławii najstarsze i najsilniejsze związki naukowe łączą Chorwację i Polskę, gdyż na studia w Akademii Krakowskiej już w dobie renesansu przyjeżdżało wielu Chorwatów. Podobnie jak w kulturze kontakty naukowe nawiązywane były najpierw poprzez osobiste relacje między studentami i uczonymi. Mowa jest o tym w angielskim opracowaniu z końca lat 60. XX wieku:

International co-operation in the scientific field specifically began, in fact, in the nineteenth century with projects which did not involve governmental participation. Cooperation was largely between individual scientists who travelled abroad to conduct research, to study, to lecture, and to discuss with other scientists matters of common concern (Pernet, 1976, 9).

Z kolei Jan Monkiewicz w cytowanej już monografii, pisząc o zagranicznej polityce naukowo-technicznej, sięga do starożytności i stwierdza, że jest to jedna z najstarszych funkcji wykonywanych przez państwo. Podaje przykład Aleksandrii za czasów Ptolemeusza I i sprowadzenia podstawowej części kadry naukowej z Aten. Dalej, przechodząc do wieków średnich, pisze o kradzieżach całych uniwersytetów przez inne miasta i kraje. Powołuje się przy tym na pracę serbskiego fizyka Stevana Dedijera i jego 
tekst pod tytułem Early migration, opublikowany w zbiorze The brain-drain (London 1968): „Początkowo przedmiotem «kradzieży» byli tylko wykładowcy, ale następnie i studenci. W wyniku kradzieży powstały między innymi uniwersytety: w Vicenzie (1204), we Florencji (1349), Padwie (1222), Oksfordzie, Cambridge itd." (Monkiewicz, Monkiewicz, Ruszkiewicz, 1989, 5). Wszystkie wspomniane formy wymiany naukowej nie stanowią przykładu współczesnych kontaktów realizowanych na zasadzie instytucjonalnej współpracy równorzędnych podmiotów. Trudno je uznać za taką mobilność naukową, jak ją dzisiaj rozumiemy, której początków należy upatrywać w okresie międzywojennym. Relacje naukowe wchodzą wówczas w sferę zainteresowania polityki zagranicznej państwa, co zbiega się z odzyskaniem przez narody południowo- i zachodniosłowiańskie niepodległości². Zaś instytucjonalizacja i dynamiczny rozwój tej dziedziny rozpoczyna się po II wojnie światowej. W międzywojniu kształtuje się koncepcja, wypracowywane są formy współpracy, ale w porównaniu do kolejnego okresu, nie można mówić o dojrzałym systemie. Dragomir Bondžić zwraca uwagę na bardzo ważny czynnik, a mianowicie brak zaufania i ostrożność we wzajemnych relacjach, co spowodowało, że w okresie międzywojennym nie osiągnęły one wysokiego poziomu:

Iako se od početka težilo da odnosi budu prožeti srdačnošću, «bratstvom», etničkom i jezičkom srodnošću i panslavizmom, fizička udaljenost i različitost osnovnih unutrašnjih i spoljnih problema sa kojima su se dve zemlje suočavale, kao i izvesno nepoverenje i opreznost, učinili su da ti odnosi ne dostignu visok nivo tokom međuratnog perioda (Bondžić, 2017, 97-98).

Na podstawie przeprowadzonych badań archiwalnych, systemu współpracy i aktów prawnych wydaje się, że ujmowanie kontaktów naukowych PRL z drugą Jugosławią jako jugosłowiańsko-polskich jest zbyt ogólnikowe. Kultura i nauka należały bowiem do jednej ze zdecentralizowanych sfer życia publicznego federacji. Poszczególne republiki miały zbyt dużą swobodę i odrębne interesy, by móc wytyczyć jakąś jedną wspólną dla wszystkich republik politykę czy kierunki współpracy ${ }^{3}$. Ponadto w istniejących

\footnotetext{
${ }^{2} \mathrm{Na}$ temat międzynarodowej współpracy intelektualnej, zdominowanej w okresie międzywojennym przez współpracę naukową, pisał Andrzej Brzeziński (2002). O chorwacko-polskiej współpracy kulturalnej Leszek Małczak (2018).

${ }^{3}$ Ten aspekt jest bardzo ważny w całym okresie. We wszelkich organach związkowych
} 
opracowaniach, ilekroć mówi się o jugosłowiańsko-polskich kontaktach, zawsze tego typu badania uprzywilejowują którąś z republik i prowadzone są z jakiegoś punktu widzenia, który trudno uznać za jugosłowiański. I choć w porównaniu do kontaktów kulturalnych aspekt narodowy w kontaktach naukowych jest mniej widoczny i oczywisty, to trudno go pomijać i traktować federację jugosłowiańską jak monolit.

Jugosławia to najbardziej zdecentralizowany i samorządny kraj spośród państw komunistycznych, choć nie można tego powiedzieć o wszystkich elementach jej ustroju. Do samego końca istnienia drugiej Jugosławii pozostały sfery scentralizowane i kontrolowane przez jeden ośrodek, aparat państwowo-partyjny. $Z$ jednej strony pod szczególnym nadzorem znajdowały się: wojsko, milicja, służby bezpieczeństwa, polityka i gospodarka, z drugiej strony kultura, oświata, nauka (choć nie wszystkie jej dyscypliny), opieka społeczna i służba zdrowia stały się dziedzinami, o których kształcie w dużej mierze decydowały poszczególne republiki. Współpraca kulturalna z zagranicą, której częścią była kooperacja naukowa, należała właśnie do takich zdecentralizowanych i samorządnych obszarów. Formalnie emancypację tej dziedziny umożliwiła Decyzja o decentralizacji kulturalno-oświatowej wymiany z zagranicą z dniem 1.01.1968 roku (Odluka o decentralizaciji kulturno-prosvetne razmene sa inostranstvom sa danom 1.01.1968.), podjęta przez Federalną Radę Wykonawczą (SIV, Savezno izvršno vijeće) 13 czerwca 1966 roku. Belgrad z czasem stał się tylko symbolicznym koordynatorem współpracy z zagranicą. Jak daleko posunął się proces decentralizacji tej sfery, świadczy próba zdyscyplinowania przez centrum republikańskich instytucji odpowiedzialnych za nią, a mianowicie uchwalona w 1981 roku Ustawa o ewidencji współpracy naukowej, kulturalnej, oświatowej i technicznej z zagranicą (Zakon o evidenciji o naučnoj, kulturnoj, prosvetnoj i tehničkoj saradnji s inozemstvom - „Službeni list SFRJ", br. 59, 28.10.1981). Nakładała ona na republikańskie instytucje

przedstawiciele poszczególnych republik zawsze reprezentowali interesy środowisk, z których się wywodzili. Istniejąca na szczeblu centralnym rada akademii, składająca się z przedstawicieli z Belgradu, Lublany i Zagrzebia, była do lat 70. XX wieku, a więc do momentu decentralizacji, bardzo ważną instytucją. Magdalena Najbar-Agičić pisze, powołując się na słowa jednego z jej członków, że przedstawiciele JAZU reprezentowali w radzie interesy swojej akademii i w ogóle życia naukowego w Ludowej Republice Chorwacji (Najbar-Agičić, 2013a, 131). 
obowiązek przekazywania do odpowiednich organów federacji m.in. danych na temat prowadzonych badań naukowych, wyjazdów na specjalizacje, wymiany ekspertów, międzynarodowej współpracy, konferencji, wymiany dokumentacji oraz informacji naukowej i technicznej, pobytów studyjnych (art. 5).

Wprawdzie Jugosławia nie była częścią bloku państw zależnych od Moskwy, ale jeśli chodzi o organizację sfery kontaktów kulturalnych i naukowych współpracowano z nią na zasadach, które obowiązywały w kontaktach z innymi krajami socjalistycznymi. Budowanie więzi i wspólnoty między Słowianami stanowiło część panującej ideologii, mogło liczyć na wsparcie instytucji państwa, które kontrolowało niemal wszystkie dziedziny życia społecznego, zaś stopień instytucjonalizacji - a instytucje wszak były państwowe - tych poszczególnych dziedzin był bardzo wysoki. Dotyczy to i Jugosławii, i Polski. Fundamentalna jednak różnica polegała na konflikcie pomiędzy dwoma różnymi systemami budowania kontaktów kulturalnych i naukowych z zagranicą, zdecentralizowanym - jugosłowiańskim, i scentralizowanym - polskim. W związku z tym, pod względem intensywności, związki Polski z Jugosławią były o wiele skromniejsze aniżeli związki Warszawy z innymi ideologicznie spokrewnionymi krajami, na co dodatkowo wpływała przejawiana przez jugosłowiańskich komunistów chęć budowania własnego, odmiennego od reszty modelu socjalizmu. Dlatego czynniki rządowe w Polsce ograniczały wzajemne relacje, starając się, by jugosłowiańska oferta kulturalna i naukowa nie przyćmiła oferty innych krajów socjalistycznych, niekoniecznie słowiańskich. Partia zazwyczaj traktowała Jugosławię jako ideologiczne zagrożenie, a sama Jugosławia nie chciała stać się jednym z krajów bloku wschodniego. Konsekwentnie realizowała swą doktrynę polityki zagranicznej - polityki niezaangażowania i współpracy z obydwoma blokami. Ponadto była bardziej zainteresowana rozwijaniem kontaktów z Zachodem, gdyż wyjazd i współpraca $z$ krajami kapitalistycznymi były dla naukowców oraz instytucji naukowych bardziej atrakcyjne i korzystne.

Autorzy pierwszego opracowania współpracy naukowej PRL z zagranicą (Krauze, Wujek, 1974), Jugosławię ulokowali w rozdziale omawiającym współpracę naukową Polski z krajami obozu socjalistycznego. W publikacji tej w żadnym miejscu nie dochodzi do głosu ,inność” Jugosławii, tj. jej faktyczna polityczna nieprzynależność do bloku państw 
socjalistycznych. W podrozdziale Podstawy formalnoprawne wspótpracy znalazł się fragment, w którym przemilczano okres politycznego konfliktu Tito ze Stalinem i całkowitego zamrożenia stosunków Jugosławii z krajami bloku wschodniego: „W 1946 r. Polska zawarła umowę o współpracy kulturalnej z Socjalistyczną Federacyjną Republiką Jugosławii, po dziesięciu latach, w roku 1956, zawarta została nowa, dostosowana do aktualnych potrzeb obu stron umowa, która obecnie jest również obowiązująca" (Krauze, Wujek, 1974, 62). Warto w tym miejscu ponownie wrócić do książki Magdaleny Najbar-Agičić (2013a, 485), która zauważa, że - jak ją nazywa - partyjną historiografię cechowały wzajemny brak zaufania i podejrzliwość, gdyż spostrzeżenie to dobrze opisuje ogólny stosunek polskich decydentów do Jugosławii.

W polsko-jugosłowiańskich aktach prawnych regulujących dziedzinę współpracy kulturalnej pomiędzy obydwoma państwami współpraca naukowa zajmuje bardzo ważne miejsce. I tak, zarówno w Konwencji o współpracy kulturalnej między Rzecząpospolitą Polską i Federacyjną Ludową Republiką Jugosławii z 1946 roku, jak i w Umowie o współpracy kulturalnej między Polską Rzecząpospolitą Ludową i Federacyjną Ludową Republiką Jugosławii z 1956 roku, która była dokumentem, obowiązującym do końca omawianego okresu, pisano o współpracy w dziedzinie nauki, kultury i oświaty, gdzie nauka, relacje instytucji naukowych, przekłady dzieł naukowych, praca naukowa, wymiana informacji w tej dziedzinie, nierzadko były wymieniane na pierwszym miejscu, sprawiając wrażenie jednej z najważniejszych kwestii w całej umowie. Szczegóły tego aktu były doprecyzowywane $\mathrm{w}$ programach jego realizacji, podpisywanych w latach 50. co roku, 60. co dwa lata, a od 1974 roku (momentu uchwalenia ostatniej jugosłowiańskiej konstytucji) co trzy lata. Powstawały one w wyniku negocjacji prowadzonych przez międzypaństwowe komisje mieszane ${ }^{4}$.

\footnotetext{
${ }^{4}$ Lista instytucji zgłaszających swoje propozycje do programu jest bardzo długa. Jeśli chodzi o polską stronę były wśród nich m.in.: Polska Akademia Nauk, Ministerstwo Nauki i Szkolnictwa, Ministerstwo Kultury i Sztuki, Ministerstwo Ochrony Środowiska i Zasobów Naturalnych, Ministerstwo Finansów, Biuro do spraw Młodzieży, Ministerstwo Oświaty i Wychowania, Robotnicza Spółdzielnia Wydawnicza „Prasa - Książka - Ruch”, Komitet do spraw Radia i Telewizji, Główny Komitet Kultury Fizycznej i Turystyki, Naczelna Dyrekcja Archiwów Państwowych, Polski Komitet ds. UNESCO, Komisja ds. Wspólnych Kontaktów Międzynarodowych Polskich Związków Młodzieży i Studentów, Naczelna Organizacja Techniczna, Towarzystwo Wiedzy Powszechnej, Polska Agencja Prasowa, Stowarzyszenie
} 
W programach tych w dziedzinie kontaktów naukowych poruszano kwestie najważniejsze. Wskazywano instytucje (uniwersytety, akademie nauk), które mogą ze sobą współpracować, określano liczbę lektoratów i uczelnie, na których mają być prowadzone, ustalano także zakres wymiany osobowej, zaś dopracowanie szczegółów współpracy powierzano wcześniej wskazanym instytucjom, które były zobowiązane do ustalenia i podpisania stosownych porozumień ${ }^{5}$. Po stronie polskiej niezmiennie wymieniano

Dziennikarzy Polskich, Stowarzyszenie Architektów Polskich, Departament I MSZ, DWKN MSZ, Ambasada PRL w Belgradzie, a przede wszystkim Wydział Zagraniczny, Wydział Kultury, Wydział Nauki, Polityki Oświatowej i Postępu Naukowo-Technicznego KC PZPR.

${ }^{5}$ Dla przykładu, można się przyjrzeć zapisom z lat 80. W programie na lata 1983, 1984, 1985 w rozdziale pierwszym I. Nauka, szkolnictwo wyższe, oświata, o każdym elemencie z tytułu rozdziału pisano w osobnym podpunkcie (A, B, C). Artykuł 2 części A, a więc dotyczącej nauki, brzmi: „Obie Strony będą popierać rozwój bezpośredniej współpracy między Polską Akademią Nauk i jej instytutami a Radą Akademii Nauk i Sztuk SFRJ oraz Polską Akademią Nauk a Akademiami Nauk i Sztuk i innymi organizacjami naukowymi w SFRJ na podstawie bezpośrednich porozumień. Strony będą także popierać nawiązywanie i rozwój bezpośredniej współpracy między towarzystwami i stowarzyszeniami naukowymi. Konkretne formy współpracy ustalone zostaną w bezpośrednich porozumieniach”. W części B, dotyczącej szkolnictwa wyższego, ustalenia są znacznie bardziej szczegółowe. W artykule 16 jednoznacznie ustala się, kto z kim może współpracować: „W okresie obowiązywania niniejszego Programu współpracować będą: Uniwersytet Warszawski, Politechnika Warszawska, Uniwersytet im. Adama Mickiewicza, Politechnika Poznańska z Uniwersytetem w Belgradzie; Uniwersytet im. Adama Mickiewicza z Uniwersytetem im. Svetozara Markovicia w Kragujevcu; Uniwersytet Warszawski, Uniwersytet Śląski w Katowicach z Uniwersytetem im. Edvarda Kardelja w Lublanie; Akademia Rolnicza w Krakowie z Uniwersytetem w Lublanie /Wydział Biotechniczny/; Akademia Ekonomiczna w Krakowie z Uniwersytetem w Sarajewie/Wydział Ekonomiczny/; Politechnika Krakowska z Uniwersytetem w Sarajewie /Wydział Budownictwa/; Uniwersytet we Wrocławiu z Uniwersytetem w Sarajewie; Politechnika Wrocławska/Instytut Górnictwa/ z Uniwersytetem w Tuzli /Wydział Górnictwa/; Uniwersytet Śląski w Katowicach z Uniwersytetem im. Djuro Pucar Stari w Banialuce; Akademia Rolnicza we Wrocławiu z Uniwersytetem w Nowym Sadzie /Wydział Rolnictwa/; Politechnika Wrocławska / Instytut Górnictwa/ z Uniwersytetem w Prisztinie /Wydział Górniczo-Hutniczy w Titowej Mitrowicy/; Wyższa Szkoła Pedagogiczna w Krakowie z Uniwersytetem w Titogradzie /Wydział Nauczycielski w Niksziciu/; Politechnika Wrocławska z Uniwersytetem w Belgradzie / Wydział Górniczo-Geologiczny w Bor/; Uniwersytet Jagielloński w Krakowie z Uniwersytetem im. Cyryla i Metodego w Skopje; Uniwersytet w Gdańsku z Uniwersytetem w Osijeku; Politechnika Warszawska z Uniwersytetem im. Dżemala Bjedića w Mostarze; Politechnika Białostocka z Instytutem Elektrotechniki im. Milana Vidmara w Lublanie; Politechnika Gdańska z Instytutem Budownictwa w Zagrzebiu; Politechnika Krakowska z Uniwersytetem im. Svetozara Markovicia w Kragujevcu; Akademia Górniczo-Hutnicza w Krakowie z Instytutem Techniki Cieplnej i Jądrowej w Sarajewie; Uniwersytet Łódzki z Uniwersytetem w Zagrzebiu; Uniwersytet Jagielloński w Krakowie z Uniwersytetem w Nowym Sadzie; Instytut 
jako najważniejszą naukową instytucję Polską Akademię Nauk. Po stronie jugosłowiańskiej tych instytucji było kilka, co zresztą nie jest wyjątkiem, lecz cechą charakterystyczną dla tego kraju, przechodzącego kilka poważnych zmian ustrojowych i kilka gruntownych reorganizacji całego aparatu państwa i jego instytucji. I tak, chronologicznie, partnerem dla PAN były: Rada Akademicka FLRJ (Akademijski savet FNRJ), Związkowa Rada ds. Pracy Naukowej (Savezni savet za naučni rad) Związkowa Rada ds. Koordynacji Działalności Naukowej SFRJ (Savezni savet za koordinaciju naučnih delatnosti), Związkowy Urząd ds. Współpracy Naukowej, Kulturalno-Oświatowej i Technicznej z Zagranicą (Savezni zavod za naučnu, kulturno-prosvetnu i tehničku saradnju) i Rada Akademii Nauk i Sztuk SFRJ ${ }^{6}$.

Polityki Naukowej, Postępu Technicznego i Szkolnictwa Wyższego w Warszawie ze Wspólnotą Szkół Wyższych Socjalistycznej Republiki Serbii w Belgradzie; Wyższa Szkoła Morska w Gdyni z Wyższą Szkoła Morską w Kotorze; Politechnika Wrocławska z Uniwersytetem w Mariborze /Wyższa Szkoła Techniczna/; Uniwersytet Łódzki /Instytut Organizacji i Zarządzania/ z Uniwersytetem w Mariborze /Wyższa Szkoła Organizacji Zarządzania w Kranju/; Uniwersytet Warszawski z Uniwersytetem im. Cyryla i Metodego w Skopje; Uniwersytet im. Mikołaja Kopernika w Toruniu z Uniwersytetem w Rijece; Uniwersytet Jagielloński w Krakowie /Instytut Biologii Molekularnej/ z Instytutem Józefa Stefana w Lublanie; Politechnika Gdańska/Instytut Fizyki/ z Uniwersytetem w Belgradzie /Instytut Fizyki/; Uniwersytet im. A. Mickiewicza w Poznaniu/Obserwatorium Astronomiczne/ z Uniwersytetem w Belgradzie /Obserwatorium Astronomiczne/; Akademia Górniczo-Hutnicza w Krakowie z Uniwersytetem w Prisztinie". Program realizacji Umowy o wspótpracy kulturalnej między Polska Rzeczapospolita Ludowa a Socjalistyczna Federacyjna Republika Jugosławii na lata 1983, 1984, 1985 podpisany w imieniu Rzadu Polskiej Rzeczypospolitej Kudowej i Zwiąkowej Rady Wykonawczej Skupsztyny Socjalistycznej Federacyjnej Republiki Jugosławiii. AMKiDN, sygn. 1509/4, s. 2, 8-10. (AMKiDN skrót od nazwy archiwum - Archiwum Ministerstwa Kultury i Dziedzictwa Narodowego).

${ }^{6}$ Savet akademija nauka FNRJ (1949-1963), po zmianie nazwy państwa z Federacyjnej Ludowej Republiki Jugosławii na Socjalistyczną Federacyjną Republikę Jugosławii - Savet akademija nauka i umetnosti SFRJ (1964-1972). Na stronie Archiwum Jugosławii można przeczytać, że działaność rady zamiera w 1972 roku, bez żadnej formalnej decyzji o jej likwidacji. Cf. http://www.arhivyu.gov.rs/active/sr-latin/home/glavna_navigacija/koriscenje_gradje/pretrazite_baze_podataka/opsti_podaci_o_fondovima_u_bazi_inventar/detalji_fonda/ params/item_id/677078.html. Trudno to w tej chwili zweryfikować; w programach realizacji umowy w drugiej połowie lat siedemdziesiątych i w latach osiemdziesiątych właśnie rada akademii jest wskazywana jako partner współpracy, a w programach zawieranych w latach osiemdziesiątych są odwołania do porozumień, w których stronę jugosłowiańską reprezentuje właśnie ta rada. Przykładowo w programie na lata 1983-1985 w rodziale I. Nauka, szkolnictwo wyższe, oświata, w podrozdziale A. Nauka, w artykule 1 zapisano: „Polska Akademia Nauk i Rada Akademii Nauk i Sztuk SFRJ będą współpracować w oparciu o Porozumienie 
Moment decentralizacji widać wyraźnie we wszystkich częściach programu, zarówno w tej odnoszącej się do kultury i sztuki, jaki i w tej traktującej o kontaktach naukowych. Od lat 70. (w programie realizacji na lata 1972 i 1973) w miejsce dawnych federalnych urzędów jako partnerów dla PAN pojawiają się oprócz organu centralnego - jak rada akademii, republikańskie akademie oraz inne instytucje naukowe ${ }^{7}$.

Ewolucja kontaktów kulturalnych i naukowych między Polską i Jugosławią polegała na stopniowej ich liberalizacji. Proces ten nasilił się w latach 70., a istotną rolę odegrały w nim zmiany ustrojowe federacji jugosłowiańskiej (ze wspomnianą już decentralizacją i samorządnością) oraz sytuacja na arenie międzynarodowej z odprężeniem w stosunkach między stronami zimnej wojny, do czego przyczyniły się m.in. obrady Konferencji Bezpieczeństwa i Współpracy w Europie zakończone 1 sierpnia 1975 roku w Helsinkach podpisaniem Aktu końcowego KBWE ${ }^{8}$. Od tego momentu W preambule programów realizacji umowy o współpracy kulturalnej zaczęto odwoływać się do zasad i postanowień tegoż dokumentu ${ }^{9}$ Znacznie

zawarte dnia 5 maja 1977 r. i Plan tematyczny współpracy, stanowiący jego integralna część”. Program realizacji Umowy o wspótpracy kulturalnej między Polska Rzeczapospolita Ludowa a Socjalistyczna Federacyjna Republika Jugosławii na lata 1983, 1984, 1985 podpisany w imieniu Rzadu Polskiej Rzeczypospolitej Kudowej i Zwiąkowej Rady Wykonawczej Skupsztyny Socjalistycznej Federacyjnej Republiki Jugosławiii. AMKiDN, sygn. 1509/4, s. 1.

${ }^{7} \mathrm{~W}$ programie na lata 1972 i 1973 figuruje następujący zapis: „Obie Strony będą popierać i wspomagać bezpośrednią współpracę między Polską Akademią Nauk i jej instytucjami z jednej strony i Akademiami Nauki i Sztuki oraz innymi instytucjami naukowymi SFRJ z drugiej w oparciu o bezpośrednie porozumienia. Polska Akademia Nauk i Związkowy Urząd do spraw Międzynarodowej Współpracy Naukowej, Oświatowo-kulturalnej i Technicznej SFRJ wymienia listy instytucji, które są zainteresowane tą bezpośrednią współpracą". Program współpracy kulturalnej między Polską Rzeczapospolita Ludową i Socjalistyczna Federacyjna Republika Jugosławii na lata 1972 i 1973. AMKiDN, sygn. 1509/4.

${ }^{8}$ Apogeum rozwoju, jak ją nazywa Lech Miodyński, poodwilżowej slawistyki, następuje w latach 70. i 80. XX wieku. Początkowo studia w zakresie jugoslawistyki istniały tylko w Warszawie i Krakowie. W połowie lat 60. uruchomiono lektorat języka serbskochorwackiego na Uniwersytecie im. Adama Mickiewicza w Poznaniu (prowadziła go urodzona w Travniku Zofia Kawecka, członkini grupy poznańskich entuzjastów Jugosławii w okresie międzywojennym, jednego z najaktywniejszych środowisk projugosłowiańskich w ówczesnej Polsce) (Pańczyk, 1982/1983, 181). W połowie lat 70. utworzono trzeci po warszawskim i krakowskim ośrodek studiów jugoslawistycznych na Uniwersytecie Śląskim w Katowicach (Miodyński, 2013, 33)

${ }^{9}$ Preambuła w latach 80 . XX wieku brzmiała: „Mając na celu dalsze pogłębianie i rozszerzanie dotychczasowej współpracy w dziedzinach nauki, szkolnictwa wyższego, oświaty, 
większa swoboda w kreowaniu kontaktów panowała w Jugosławii. Z jednego z raportów na temat realizacji programu współpracy kulturalnej między PRL i SFRJ na lata 1974-1976, sporządzonego przez radcę ambasady polskiej w Belgradzie Antoniego Mirka-Olchę, wyłania się obraz stosunkowo swobodnych kontaktów:

Faktyczne rozmiary i stopień owocności tej współpracy trudno tu rzeczowo ocenić, ponieważ współdziałanie uczelni wyższych i podległych im instytutów opiera się na bezpośrednich porozumieniach, a często jeszcze na osobistych kontaktach poszczególnych naukowców. Rola Ambasady polegała tu w ubiegłym trzyleciu na ułatwianiu i inspirowaniu kontaktów w konkretnych sprawach /kongresy, zjazdy, wizyty studyjne itp./ (A. Mirek-Olcha: Realizacja programu wspótpracy kulturalnej między PRL i SFRJ na lata 1974-1976. AMKiDN, sygn. 1509/15, s. 2-3).

Na rolę kontaktów osobistych zwracają uwagę historycy, między innymi Dominik Pick w monografii poświęconej polsko-zachodnioniemieckim stosunkom w PRL:

instytucje naukowe, jak również poszczególni naukowcy cieszyli się stosunkowo dużym zakresem autonomii w swoich działaniach. Wynikało to m.in. ze specyfiki kontaktów naukowych, które podobnie jak kontakty kulturalne, trudno rozwijać bez prywatnych, nieoficjalnych znajomości, nawiązywanych zarówno przy okazjach oficjalnych (np. podczas negocjacji nad umowami o współpracę), jak też w kuluarach konferencji czy nawet $\mathrm{w}$ trakcie przypadkowych spotkań. $\mathrm{Z}$ tego też powodu kontakty nawiązywane za granicą przez polskich naukowców były jedynie w ograniczonym zakresie znane władzom polskim, które tym samym nie były w stanie ich kontrolować (Pick, 2016, 260).

Pick podaje w tym samym miejscu przykład podpisania przez Uniwersytet Warszawski porozumienia o współpracy z Tybingą bez powiadomienia Ministerstwa Spraw Zagranicznych czy Ministerstwa Nauki.

kultury i sztuki, środków masowego przekazu, kultury fizycznej i sportu, zgodnie z artykułem 6 Umowy o współpracy kulturalnej między Polską Rzecząpospolitą Ludową a Socjalistyczną Federacyjną Republiką Jugosławii, podpisanej w Belgradzie dnia 6 lipca 1956 r. oraz uwzględniając zasady i postanowienia Aktu Końcowego Konferencji Bezpieczeństwa i Współpracy w Europie, obie Strony uzgodniły następujący Program współpracy kulturalnej między Polską Rzecząpospolitą Ludową a Socjalistyczną Federacyjną Republiką Jugosławii na lata 1980, 1981 i 1982”. Program realizacji Umowy o wspólpracy kulturalnej między Polska Rzeczapospolita Ludowa a Socjalistyczna Federacyjna Republika Jugosławii na lata 1980, 1981 i 1982. AMKiDN, sygn. 1509/4, s. 1. 
Niemniej nie można zapomnieć o toczącej się w tle wojnie ideologicznej i rywalizacji obu światów podzielonych żelazną kurtyną. Wymownie świadczy o tym książeczka wydana w 1977 roku przez Książkę i Wiedzę pt. Prawda o wymianie kulturalnej, będąca tłumaczeniem z języka rosyjskiego. Stanowi ona zbiór odpowiedzi udzielonych przez przedstawicieli rosyjskiej nauki i instytucji państwowych związanych z nauką na pytania „Literaturnej gaziety". Redaktor naczelny tego wielokrotnie tłumaczonego na łamach polskiej prasy pisma stwierdza we wstępie, że zbiór obala „w przekonujący sposób, liczne oszczerstwa burżuazyjnej propagandy odnośnie polityki pierwszego państwa socjalistycznego w dziedzinie kontaktów naukowych, kulturalnych i wymiany turystycznej" (Prawda..., 1977, 7).

Aby móc pokusić się o całościową ocenę relacji naukowych, należałoby odbyć kwerendy w wielu instytucjach. Byłyby to bardzo kosztowne, praco- i czasochłonne badania (właściwie to zadanie dla zespołu badawczego; konieczne byłoby przeprowadzenie kwerendy w wielu miejscach, ograniczając się tylko do polskich, należałoby m.in. zapoznać się z dokumentami następujących ośrodków: Wydziału Nauki i Oświaty KC PZPR, MSZ, MNiSW, PAN, uniwersytetów i innych placówek naukowych). Na podstawie badań, które prowadziłem na temat kontaktów kulturalnych, i zebranych materiałów oraz informacji mogę pokusić się o stwierdzenie, że mechanizmy i zasady współpracy naukowej były zbliżone do tych, które obowiązywały w przypadku kultury, oraz że typologia instytucji występujących w tej sferze ma swoje odpowiedniki w świecie nauki.

Po upadku komunizmu transformacja ustrojowa objęła wszystkie dziedziny życia społecznego. Zmiany geopolityczne oraz gospodarcze i społeczne otworzyły nowy okres w kontaktach naukowych Polski z zagranicą. Dzisiaj państwo nie steruje i nie programuje ich w takim stopniu jak w PRL. Więcej zależy od samych instytucji i podmiotów współpracy, a czynnik ideologiczny odgrywa mniejszą rolę. Ograniczenia mają obecnie inny charakter. Kraje słowiańskie utraciły swoją uprzywilejowaną pozycję względem szeroko rozumianego Zachodu, w PRL wrogiego ideologicznie wobec wszystkich państw słowiańskich. Zjawiska, jakie zaszły w polu kulturalnym i naukowym pod wpływem czynników geopolitycznych, doprowadziły do marginalizacji obecności kultur słowiańskich w Polsce, odbiły się również na kontaktach naukowych (współpraca o wiele szybciej rozwija się z krajami niesłowiańskimi). W krajach słowiańskich, w tym 
w Polsce, istnieje realna groźba zaniku slawistyki jako odrębnej dyscypliny (tak się dzieje w krajach zachodnich, które, wcześniej motywowane czynnikiem politycznym, po upadku muru berlińskiego utraciły zainteresowanie krajami słowiańskimi). Być może, po okresie dynamicznego rozwoju w latach 90. XX wieku, zostanie ona ograniczona do kilku ośrodków akademickich i będzie wegetować jako lektorat lub dodatek do innych kierunków. Nieunikniona wydaje się jej fuzja z większymi dyscyplinami.

Obecny zwrot ku Zachodowi w połączeniu z procesami globalizacji sprawił, że jesteśmy świadkami największego kryzysu poczucia wspólnoty wśród krajów słowiańskich, pierwszego tak silnego i głębokiego od romantyzmu i ruchów odrodzeniowych. Uderza on we wszystkie sfery międzysłowiańskich kontaktów i nie sprzyja rozwojowi współpracy naukowej. Wydaje się jednak, że na - w pełnym tego słowa znaczeniu - globalnym rynku nauki wciąż będzie miejsce na kooperację między Polską i innymi krajami słowiańskimi, choć jej rozwój w obliczu braku instytucjonalnych bodźców w jeszcze większej mierze będzie zależał od indywidualnych kontaktów wśród naukowców oraz ich inicjatyw i zaangażowania, a jej znaczenie będzie miało lokalny charakter.

\section{Wykorzystane materiały archiwalne}

Sygnatura 1509/15. Mirek-Olcha, A. Realizacja programu wspótpracy kulturalnej między PRL i SFRJ na lata 1974-1976. Archiwum Ministerstwa Kultury i Dziedzictwa Narodowego.

Sygnatura 1509/4. Program realizacji Umowy o wspótpracy kulturalnej między Polska Rzeczapospolita Ludowa a Socjalistyczna Federacyjna Republika Jugostawii na lata 1980, 1981 i 1982. Archiwum Ministerstwa Kultury i Dziedzictwa Narodowego.

Sygnatura 1509/4. Program realizacji Umowy o wspótpracy kulturalnej między Polska Rzeczapospolita Ludowa a Socjalistyczna Federacyjna Republika Jugostawii na lata 1983, 1984, 1985 podpisany w imieniu Rzadu Polskiej Rzeczypospolitej Ludowej i Zwiazkowej Rady Wykonawczej Skupsztyny Socjalistycznej Federacyjnej Republiki Jugosławii. Archiwum Ministerstwa Kultury i Dziedzictwa Narodowego.

Sygnatura 1509/4. Program wspótpracy kulturalnej między Polska Rzeczypospolita Ludowa i Socjalistyczna Federacyjna Republika Jugosławii na lata 1972 i 1973. Archiwum Ministerstwa Kultury i Dziedzictwa Narodowego. 


\section{Literatura}

Bondžić, D. (2014). Saradnja jugoslavenskih i poljskih univerziteta 1945-1960. W: Polska i Jugosławia $w$ stosunkach międzynarodowych po II wojnie śiwtaowej. Relacje wielostronne i wielopoziomowe. Red. M. Pavlović, A. Zaćmiński. Bydgoszcz: Wydawnictwo Uiwersytetu Kazimierza Wielkiego, s. 307-322.

Bondžić, D. (2015). Saradnja Jugoslavije i Poljske u oblasti nuklearne energije krajem 50-ih godina. W: Jugoslavensko-poljski odnosi u XX veku. Ur. M. Pavlović, A. Zaćminski, D. Bondžić. Beograd: Institut za savremenu istoriju - Instytut Historii i Stosunków Międzynarodowych UKW, s. 285-302.

Bondžić, D. (2017). Prosvetna, naučna i kulturna saradnja Kraljevine SHS / Jugoslavije i Poljske između dva svetska rata. W: Jugoslavija i Poljska u XX veku. Ur. M. Pavlović, A. Zaćmiński, P. Wawryszuk. Beograd: Institut za savremenu istoriju - Instytut Historii i Stosunków Międzynarodowych UKW - Društvo istoričara Srbije „Stojan Novaković”, s. 97-114.

Brzeziński, A. (2002). Polska w systemie międzynarodowej wspótpracy intelektualnej Ligi Narodów (1922-1939). „Dzieje Najnowsze” nr 2, s. 3-22.

Connelly, J., (2014). Zniewolony uniwersytet. Sowietyzacja szkolnictwa wyższego w Niemczech Wschodnich, Czechach i Polsce 1945-1956. Przeł. W. Rodkiewicz. Warszawa: Instytut Historii Nauki im. Ludwika Aleksandra Birkenmajerów Polskiej Akademii Nauk.

Haliżak, E. (1988). Wspótpraca naukowo-techniczna Wschód-Zachód. Warszawa: Wydawnictwa Uniwersytatu Warszawskiego.

Krauze, W., Wujek, T. (1974). Wspótpraca naukowa Polski Ludowej z zagranicą. Warszawa: Książka i Wiedza.

Małczak, L. (2013). Croatica. Literatura i kultura chorwacka w Polsce w latach 1944-1989. Katowice: Wydawnictwo Uniwersytetu Śląskiego.

Małczak, L. (2018). (Nie)obecność literatury chorwackiej w Polsce - okres międzywojenny. W: Wieża Babel, t. 1: Kultura i dialog. Red. J. Czaja, I. Jermaszowa, M. Wójciak, B. Zieliński. Poznań: Wydawnictwo Naukowe Uniwersytetu im. Adama Mickiewicza, s. 17-35.

Miodyński, L. (2013). Literaturoznawstwo slawistyczne w Polsce od powojennego planu rozwojowego do międzyepoki transformacji. „Pamiętnik Słowiański” nr 63.

Monkiewicz, G., Monkiewicz, J., Ruszkiewicz, J. (1989). Zagraniczna polityka naukowo-techniczna Polski. Diagnoza. Uwarunkowania. Kierunki. Wrocław: Ossolineum.

Najbar-Agičić, M. (2013a). Kultura, znanost, ideologija. Prilozi istraživanju politike komunističke vlasti u Hrvatskoj od 1945. do 1960. na polju kulture i znanosti. Zagreb: Matica hrvatska.

Najbar-Agičić, M. (2013b). U skladu s marksizmom ili činjenicama? Hrvatska historiografia 1945-1960. Zagreb: Ibis grafika.

Pańczyk, H. (1982/1983). Problematyka badań nad literaturami zachodnio- i południowostowiańskimi w UAM w 35-leciu PRL. „Studia Rossica Posnaniensia” 17. 
Pernet, A. (ed.) (1976). Guide to World Science. International Science, vol. 16. $2^{\text {nd }}$ ed. Guernsey, British Isles: Francis Hodgson.

Pick, D. (2016). Ponad żelazną kurtyną. Kontakty społeczne między PRL i RFN w okresie détente $i$ stanu wojennego. Warszawa: Instytut Pamięci Narodowej.

Prawda o wymianie kulturalnej. (1977). Warszawa: Książka i Wiedza.

Sławiński, J. (1990). Teksty i teksty. Warszawa: Wydawnictwo PEN.

Zakon o evidenciji o naučnoj, kulturnoj, prosvetnoj i tehničkoj saradnji s inozemstvom. „Službeni list SFRJ” br. 59, 28.10.1981. 